\title{
Over selectieve eters: een strijd aan tafel
}

In deze bijdrage willen we aandacht besteden aan voedingsproblemen op jonge leeftijd. Na een definiëring en afbakening, schetsen we de eetontwikkeling en hoe individuele kenmerken deze beïnvloeden. Ten slotte willen we ingaan op hoe de omgeving en meer specifiek het gezin als belangrijkste leeromgeving het proces van smaakacceptatie kan sturen en ondersteunen.

door Ellen Moens \& Julie Vandewalle

E. Moens en J. Vandewalle zijn beiden als obesitasonderzoekers verbonden aan de vakgroep Ontwikkelings-, Persoonlijkheids- en Sociale Psychologie van de Universiteit Gent (ellen.moens@ugent.be). Daarnaast zijn zij werkzaam in universitair psychologisch centrum Kind \& Adolescent, een ambulant centrum voor kinderen en jongeren. Ellen Moens ontwikkelde en evalueerde een protocol voor de begeleiding van ouders van kinderen met eet- en gewichtsproblemen. Van haar werkboek is een Vlaamse en Nederlandse versie op de markt.

Verscheidene studies wijzen op een afnemende kwaliteit van het voedingspatroon van jonge kinderen. Dit resulteert in een energierijke voedselinname, met veel suikers, verborgen vetten en weinig voedingswaarde. Vooral de fruit- en groenteconsumptie van kinderen is laag en ligt bijzonder ver af van de aanbevolen vijf porties per dag. Dit zou vooral te maken hebben met de voedselvoorkeuren van kinderen. Surveys tonen dat groenten behoren tot de minst geprefereerde voedingscategorie van kinderen (1). Toch is er sterke evidentie voor het gunstige effect van het eten van fruit en groenten op de algemene gezondheid en op de preventie van overgewicht op jonge leeftijd in het bijzonder (2). Ouders en verzorgers staan dus voor de uitdaging om jonge kinderen een evenwichtig en gevarieerd eetpatroon aan te leren. De aangeboren voedselvoorkeuren en de ontwikkeling van smaakperceptie bij kinderen kunnen dit proces echter bemoeilijken. We gaan nu eerst in op de definiëring en afbakening van voedingsproblemen bij jonge kinderen. 


\section{Definiëring van voedingsproblemen bij jonge kinderen}

Voedingsproblemen kunnen ontstaan wanneer er moeilijkheden zijn in de ontwikkeling van een aantal fysische functies en/of vaardigheden in interactie met de context van het jonge kind (3). Dit kan tot uiting komen in de volgende problemen: (a) een vertraagde of afwezige ontwikkeling van eetvaardigheden; (b) moeilijkheden met bepaalde voedingstexturen; (c) weigering van voeding op basis van smaak, textuur of andere sensorische factoren; (d) gebrek aan eetlust of interesse in voeding; of (e) het hanteren van voeding als troost of zelfstimulering. Deze gedragingen komen vaak voor. Ongeveer $25-45 \%$ van de kinderen ervaren in enige mate eetproblemen. De meeste van deze problemen zijn ontwikkelingsgerelateerd en gaan bijgevolg vanzelf over. Zolang zij niet gepaard gaan met een significant gewichtsverlies, een falen om in gewicht toe te nemen of een beperking in de groei, behoeft dit geen klinische opvolging (3). $\mathrm{Er}$ kan echter wel een probleem ontstaan wanneer het kind en zijn verzorgers vast komen te zitten in één van deze ontwikkelingen. Alvorens daar op in te gaan is het van belang deze eetproblemen duidelijk te onderscheiden van de eet- en voedingsstoornissen die beschreven worden in de DSM-IV-TR (4).

Onder de rubriek Voedings- en eetstoornissen op zuigelingenleeftijd of vroege kinderleeftijd onderscheidt de DSM-IV-TR drie afzonderlijke voedingsstoornissen. Pica wordt gedefinieerd als het hardnekkig eten van niet voor consumptie geschikte stoffen. De ruminatiestoornis refereert naar een herhaalde regurgitatie en herkauwen van voedsel. Ten slotte is er de voedingsstoornis op vroege kinderleeftijd waarbij het kind er nooit in slaagt voldoende te eten met een in significante mate uitblijven van gewichtstoename of een significant gewichtsverlies gedurende ten minste één maand. Daarnaast beveelt Eetexpert (5) (zie ook bijdrage over Eetexpert in dit nummer) in navolging van internationale experts aan om gebruik te maken van de termen voedingsprobleem en voedingsstoornis voor kinderen jonger dan zes jaar en van eetprobleem en eetstoornis voor kinderen ouder dan zes jaar. Met 'probleem' wordt verwezen naar een symptoom van een psychische stoornis of lichamelijke aandoening. 'Stoornis' daarentegen refereert naar een syndroom waarin het gestoorde eetgedrag de centrale component is. 
Deze bijdrage wil zich richten op selectief eten, wat - afhankelijk van de leeftijdgedefinieerd wordt als een voedings- of eetprobleem waarbij een veelheid aan smaken en/of texturen niet geaccepteerd wordt, hetgeen resulteert in een eenzijdig eetpatroon. De oorsprong is terug te vinden in de vroege ontwikkeling van specifieke individuele vaardigheden in interactie met omgevingsinvloeden.

\section{De ontwikkeling van voedselvoorkeuren bij kinderen in relatie met individuele kenmerken}

In het algemeen verloopt de ontwikkeling van voedselvoorkeuren bij kinderen in drie stadia. Gedurende de eerste helft van het eerste levensjaar worden baby's blootgesteld aan één enkel voedingsitem, melk. In het geval van flesvoeding, is dit eerder een monotone smaakervaring. Bij borstvoeding wordt het jonge kind blootgesteld aan een variëteit van smaken. Studies richten zich ook op invloeden nog vroeger in de ontwikkeling van het kind, met name op de zwangerschap zelf. Daarin werd aangetoond dat smaken wel degelijk doorgegeven kunnen worden aan het kind via het vruchtwater (6). Tijdens dit eerste levensjaar, hebben kinderen een voorkeur voor zoete en zoute smaken en bijgevolg de neiging om bittere en zure voedingsmiddelen te verwerpen (7). Dit betekent dat bij de overgang naar vaste voeding, het kind voor de uitdaging komt te staan om nieuwe smaken te leren accepteren.

In de tweede periode van de eetontwikkeling (tussen 18 maanden en 2 jaar), treedt echter neofobie op, gedefinieerd als angst voor en verwerping van nieuw, onbekend voedsel. Neofobie komt in mindere of meerdere mate voor bij alle kinderen en verklaart waarom kinderen op die leeftijd niet veel lusten. Desondanks blijken sommige kinderen gevoeliger te zijn voor neofobie. Een tweelingenstudie toonde een erfelijkheidsfactor bij neofobie van $78 \%$ (8). Daarnaast zijn er bepaalde persoonlijkheidstrekken die meer voorkomen bij neofobische kinderen. Met name kinderen die van nature angstiger zijn, meer stressgevoelig en minder sensatie zoekend zouden weigerachtiger staan tegenover onbekende voeding (9). Het kan van belang zijn deze persoonlijkheidstrekken mee in kaart te brengen wanneer een gezin hulp zoekt voor een uit de hand gelopen neofobie. Naast ouderlijke coaching kan ook een begeleiding van het jonge kind zelf aangewezen zijn. 
In de derde fase (na twee jaar), krijgen de voedselvoorkeuren verder vorm in relatie tot de sociale context en geassocieerde fysiologische gevolgen. Zo verkiezen kinderen al op deze jonge leeftijd een energierijke maaltijd boven een energie-arme omwille van het spanningsreducerende effect ervan (10). Dit blijkt bovendien samen te hangen met het temperament van het kind. Beloningsgevoelige kinderen zouden sensitiever zijn voor een beloning in de nabije toekomst. Toekomstig onderzoek moet zich richten op hoe deze temperamentsfactor de ontwikkeling van voedselvoorkeuren bij kinderen meestuurt. In deze derde periode kan 'picky eating' voorkomen: het weigeren van inname van bekend voedsel, hetgeen resulteert in een weinig gevarieerd eetpatroon (9).

Zeker neofobie, maar ook 'picky eating' passen binnen een typisch verloop van de eetontwikkeling, maar vormen tegelijk de grootste psychologische barrières in de ontwikkeling naar een gevarieerd en gezond eetpatroon (9). Terwijl beide concepten sterk -op elkaar lijken, is het van belang ze van elkaar te onderscheiden, vooral voor de opvolging ervan. Neofobie refereert naar de verwerping van voeding op basis van het zien en/of de geur ervan. Op het moment dat het voedingsitem in de mond genomen wordt, is de neofobie als angstreactie eigenlijk overwonnen. Wanneer kinderen de smaak en/of de textuur blijven verwerpen, kunnen zij evolueren naar picky eaters. Veelvuldige blootstelling aan verschillende voedingsitems helpt om neofobie te overwinnen; bij picky eating daarentegen zijn ook andere leerwetten van gedragsverandering nodig. Bij beiden wordt hierbij de rol van de omgeving erkend. Dit wordt hieronder verder toegelicht.

\section{Hoe kunnen verzorgers de ontwikkeling van een gevarieerd eetpatroon ondersteunen?}

De ontwikkeling van het eetgedrag van kinderen wordt sterk gestuurd door de sociale context in het algemeen en door concreet ouderlijk gedrag in het bijzonder. Eerst en vooral zijn ouders verantwoordelijk voor het type voedsel dat zij ter beschikking stellen van de kinderen. Uit onderzoek blijkt immers dat zowel de fruit- en groenteconsumptie sterk gestuurd wordt door de beschikbaarheid maar ook door de toegankelijkheid ervan. Kinderen eten vaker fruit en groenten 
wanneer het in hapklare porties wordt aangeboden, en dit bleek vooral te gelden voor kinderen met weinig voorkeur voor deze voedingsgroepen (11). Toch is het verder van belang om ook enig 'proefbeleid' in het gezin door te voeren (7). Onderzoek toont dat er verschillende ouderlijke strategieën onderscheiden worden die de voedselvoorkeur en de consumptie van voeding beïnvloeden: (a) herhaalde blootstelling; (b) modeling en rewarding; (c) en ouderlijke aanmoediging.

a. Herhaalde blootstelling aan nieuwe voedingsitems

Het positieve effect van herhaalde blootstelling op de voorkeur voor bepaalde voedingsmiddelen werd reeds gevonden in verschillende studies (12). Het theoretische principe achter deze interventie is afkomstig van de Leertheorie, en meer specifiek de 'mere exposure hypothese', die stelt dat herhaaldelijke exposure aan een bepaalde stimulus de waardering ervan bevordert (13). Een belangrijke vraag is dan ook hoeveel blootstellingen er gemiddeld nodig zijn voordat kinderen gewend zijn aan het zien of de smaak van een voedingsmiddel. Dit blijkt afhankelijk te zijn van de leeftijd (vlotter bij jonge kinderen), van het type voedsel (vlotter bij fruit dan bij groenten) en zou variëren van 3 tot 15 blootstellingen (14). Deze interventie zou vooral helpen om kinderen minder weigerachtig te laten zijn voor bepaalde voedingsmiddelen. Om kinderen effectief te laten proeven en ervaren dient blootstelling in combinatie met één of andere vorm van instructie aangeboden te worden (7).

\section{b. Modeling \& rewarding}

Volgens de originele theorie van sociaal leren van Bandura (15), heeft modeling een belangrijke betekenis in het proces van gedragsverandering. Kinderen zullen vooral het gedrag van een ander overnemen wanneer zij: (a) het model graag mogen; (b) kunnen waarnemen dat het model beloond wordt; (c) er zelf voor beloond worden en (d) zien dat het gedrag gemodelleerd wordt door verscheidene personen.

Idealiter vindt modeling van gezonde voedingskeuzes plaats tijdens een gezinsmaaltijd. Onder invloed van maatschappelijke veranderingen, verliezen gezinsmaaltijden het laatste decennium echter steeds meer terrein. Toch is het positieve effect ervan op de voedingskeuzes, maar ook op het algemene psychosociale welzijn van kinderen en jongeren (16) duidelijk aangetoond. 
Echter, ouders kunnen ook model staan voor ongezond eetgedrag. Overmatig snel eten, maar ook ontremd eetgedrag bij kinderen blijkt althans gedeeltelijk te verklaren door de attitudes en het eetgedrag van hun moeders, via het principe van ouderlijke modeling (17). Werken met ouders rond de verschillende functies van gezinsmaaltijden en de manier waarop zij eetgedrag naar hun kinderen toe modelleren, blijken belangrijke interventies te zijn.

Het effect van beloningen in het voedingsdomein lijkt afhankelijk te zijn van het specifieke doel van de beloning. Wanneer voeding zelf als beloning gebruikt wordt, zou dit de voorkeur voor dat voedsel verhogen (18). Het hanteren van beloningen voor het opeten van de groenten is echter een averechtse strategie gebleken. De afkeur voor de groenten zou er enkel maar door toenemen (7). Toch blijkt uit een kwalitatieve bevraging dat moeders geen negatieve effecten van beloningen rapporteren. Het bereiken van acceptabel eetgedrag was echter eerder een doel dat moeders primair nastreefden dan het beïnvloeden van de voedselvoorkeuren (19). Dit kan een belangrijk gegeven zijn om te bevragen bij ouders.

\section{Ouderlijke aanmoediging}

Alhoewel er vaak aangegeven wordt dat aanmoediging tot proeven een adaptieve strategie is die ouders hanteren, is er geen duidelijke definiëring van dit concept. De strategie waarbij ouders kinderen onder druk zetten om te eten kan beschouwd worden als de maladaptieve manier van ouderlijke aanmoediging en is daarentegen veel vaker onderzocht. $\mathrm{Er}$ werden negatieve effecten gevonden van het hanteren van druk zowel op wat kinderen eten als op de hoeveelheid. Zo zou dit niet alleen resulteren in een toegenomen afkeer voor het product (7), maar tevens in een afgenomen sensitiviteit voor honger- en verzadigingscues. Dit kan aanleiding geven tot ontremd eetgedrag (20).

Ouders kunnen wel aanmoedigen om te proeven. Gemiddeld blijken er 5 à 10 proefbeurten nodig te zijn vooraleer een kind kan wennen aan een nieuwe smaak of textuur (7). Het is daarbij aan de ouders om zelf model staan. In dit opzicht zijn voeding en opvoeding onlosmakelijk met elkaar verbonden. Het kind moet hierbij de mogelijkheid hebben om wat het proeft in een servetje terug uit te spugen. Op deze manier, kan het kind op zijn eigen tempo, zonder druk of dreiging, ervaringen opdoen met nieuwe smaken en texturen. Het is bovenal de 
bedoeling dat (het proeven van) fruit en groenten een positieve associatie krijgt, wat enkel mogelijk is in een rustige, positieve en aanmoedigende context.

\section{Richtlijnen voor ouders bij het sturen van gevarieerde smaakacceptatie bij hun kind}

- Borstvoeding biedt kinderen een vroegtijdige kennismaking met een grotere variëteit aan smaken.

- Kinderen herhaaldelijk blootstellen aan een nieuw voedingsitem, bij voorkeur in hapklare porties, kan de weigerachtigheid van het kind ervoor verminderen.

- Als ouder een moedig model zijn door zelf te proeven van minder geprefereerde voeding, stimuleert kinderen tot proeven.

- Het hanteren van beloningen voor het opeten van geweigerd voedsel wordt best vermeden. Deze techniek kan namelijk leiden tot een stijging in afkeur voor het voedingsitem.

- Een positieve sfeer aan tafel doet eten.

\section{Conclusie}

Ontwikkeling van smaak- en voedselvoorkeuren houden bij kinderen dus een leerproces in. Neofobie is hierbij een normaal ontwikkelingsproces maar vormt tegelijk de belangrijkste barrière. Het overwinnen ervan vraagt een positieve ouderlijke ondersteuning waarbij het doel het verwerven van een evenwichtig en gevarieerd eetpatroon is op lange termijn. Harris (21) hanteert de term 'programming' en duidt op het belang om zo vroeg mogelijk in de ontwikkeling het leerproces te starten. Herhaalde blootstelling aan gevarieerde voeding en smaken, in combinatie met modeling en een mild proefbeleid, zijn efficiënte strategieën, ook voor kinderen die, afhankelijk van hun temperament, meer gevoelig zijn voor neofobie. Dit pleit voor preventieve acties bij voorkeur reeds tijdens de zwangerschap en zeker reeds tijdens het eerste levensjaar van het kind.

\section{Noten}

(1) Guenther PM ea (2006) Most Americans eat much less than recommended amounts of fruits and vegetables. J ournal of the American Dietetic Association 106: 1371-1379 
(2) Epstein LH ea (2000) Problem solving in the treatment of childhood obesity. Journal of consulting and clinical psychology 68: 717-721

(3) Bryant-Waugh R ea (2010) Feeding and eating disorders in childhood. International journal of eating disorders 43: 98-111

(4) American Psychiatric Association (2000) Diagnostic and statistical manual of mental disorders ( $4^{\text {th }}$ ed. text rev.). Washington, DC: American Psychiatric Association

(5) Eetexpert.be (2008) Zorg voor kinderen met eet- en gewichtsproblemen: Draaiboek vroegdetectie CLB. Brussel: Vlaamse Gemeenschap, Ministerie van Welzijn (verkrijgbaar via vzw Eetexpert.be)

(6) Mennella JA ea (2001) Prenatal and postnatal flavor learning by human infants. Pediatrics 107: e88

(7) Birch LL (1999) Development of food preferences. Annual review of nutrition 19: 4162

(8) Cooke LJ ea (2007) Genetic and environmental influences on children's food neophobia. American journal of clinical nutrition 86: 428-433

(9) Dovey TM ea (2008) Food neophobia and 'picky/fussy' eating in children: a review. Appetite 20: 181-193

(10) Birch LL \& Fisher JO (1998) Development of eating behaviours among children and adolescents. Pediatrics 101: 539-549

(11) Cullen KW ea (2003) Availability, accessibility and preferences for fruit, $100 \%$ fruit juice and vegetables influence children's dietary behavior. Health education \& behavior 30: $615-626$

(12) Sullivan SA \& Birch LL (1994) Infant dietary experience and acceptance of solid foods. Pediatrics 93: 271-277

(13) Zajonc RB (1968) Attitudinal effects of mere exposure. Journal of personality and social psychology 9: Monograph supplement No. 2, Part 2

(14) Horne PJ ea (2004) Increasing children's fruit and vegetable consumption. A peermodelling and rewards-based intervention. European journal of clinical nutrition 58: $1649-1660$

(15) Bandura A (1971) Social learning theory. New York: General Learning Pressl

(16) Eisenberg ME ea (2004) Correlations between family meals and psychosocial wellbeing among adolescents. Archives of pediatric and adolescent medicine 158: 792-796

(17) Pike KM \& Rodin J (1991) Mothers, daughters and disordered eating. Journal of abnormal psychology 100: 198-204

(18) Mikula G (1989) Influencing food preferences of children by 'if-then' instructions. European journal of social psychology 19: 225-241

(19) Moore SN ea (2007) Feeding strategies used by mothers of 3-5-year-old children. Appetite 49: 704-707

(20) Galloway AT ea (2006) 'Finish your soup': Counterproductive effects of pressuring children to eat on intake and affect. Appetite 46: 318-323

(21) Harris G (2008) Development of taste and food preferences in children. Current opinion in clinical nutrition and metabolic care 11: 316-319 